Research article

\title{
Comparative effect of arbuscular mycorrhiza, cowdung and phosphorus on growth and yield contributing characters of red amaranth (Amaranthus tricolor L.) and Indian spinach (Basella alba L.)
}

\author{
Aporna Ghosh $^{1}$, Md. Tahjib-Ul-Arif ${ }^{2}$, S. G. Chamely ${ }^{1}$, M. R. Haque ${ }^{2}$, \\ Md. Mokhlesur Rahman ${ }^{1}$ and Md. Asadul Haque Bhuiyan ${ }^{3}$
}

\author{
${ }^{1}$ Department of Agricultural Chemistry, Bangladesh Agricultural University, Mymensingh-2202, Bangladesh \\ ${ }^{2}$ Department of Biochemistry and Molecular Biology, Bangladesh Agricultural University, Mymensingh-2202, \\ Bangladesh \\ ${ }^{3}$ Soil Science Division, Bangladesh Agricultural Research Institute, Gazipur, Bangladesh
}

*Corresponding Author: arif1002215@gmail.com

[Accepted: 22 June 2017]

\begin{abstract}
A pot experiment was conducted to study the effect of arbuscular mycorrhiza, cowdung and phosphorus on red amaranth and Indian spinach in the net house of the Department of Agricultural Chemistry, Bangladesh Agricultural University, Mymensingh. The experiment was laid out in a Completely Randomized Design (CRD) with five replications and 8 treatment combinations comprised of $\mathrm{T}_{1}$ : Control, $\mathrm{T}_{2}$ : Arbuscular mycorrhiza (AM), $\mathrm{T}_{3}$ : Cowdung (CD), $\mathrm{T}_{4}$ : Phosphorus (P), $\mathrm{T}_{5}: \mathrm{AM}+\mathrm{CD}, \mathrm{T}_{6}: \mathrm{CD}+\mathrm{P}, \mathrm{T}_{7}: \mathrm{AM}+\mathrm{P}$ and $\mathrm{T}_{8}: \mathrm{AM}+\mathrm{CD}+\mathrm{P}$. Red amaranth (Amaranthus tricolor L.) cv. BARI Lalshak-1 and Indian spinach (Basella alba) cv. BARI Puishak-1 were used as test crops for the experiment. The experimental results showed that there were significant differences in growth and yield characters such as plant height, plant diameter, number of leaves per plant, shoot fresh and dry weights, root fresh and dry weights of red amaranth and Indian spinach due to the application of arbuscular mycorrhiza (AM), cowdung (CD) and phosphorus (P) independently and combinedly. When arbuscular mycorrhiza, CD and phosphorus were applied combinedly, it exhibited a remarkably higher response in growth and yield of these vegetables.
\end{abstract}

Keywords: Arbuscular mycorrhiza - Biofertilizer - Cowdung - Phosphorus - Growth and yield.

[Cite as: Ghosh A, Tahjib-Ul-Arif M, Chamely SG, Haque MR, Rahman MM \& Bhuiyan MAH (2017) Comparative effect of arbuscular mycorrhiza, cowdung and phosphorus on growth and yield contributing characters of red amaranth (Amaranthus tricolor L.) and Indian spinach (Basella alba L.). Tropical Plant Research 4(2): 254-263]

\section{INTRODUCTION}

The arbuscular mycorrhiza (AM) helps most of the plant species in the uptake of moisture and nutrients from the soil by forming symbiotic association with roots (Marschner \& Dell 1994). Arbuscular mycorrhizas (AMs) are a unique example of symbiosis between two eukaryotes, soil fungi and plants. This association induces important physiological changes in each partner that lead to reciprocal benefits mainly in nutrient supply (Balestrini \& Lanfranco 2006). The external AM hyphae extend several centimeters from the infected root surface and help in the exploration of greater soil volume to absorb nutrients and moisture from the soil. Besides, they increase the rate of photosynthesis and enhance production of growth regulating substances in the host plants (Danneberg et al. 1993). The benefit of mycorrhizae to plant nutrients is especially phosphorus. Because of such benefits, the AM fungi can be used as bio-fertilizer for enhancing growth and yield of most crop plants.

Field responses were often unsatisfactory; especially in high-input agricultural systems where it is concluded by many that the mycorrhizae had little practical importance in agriculture. It is a well-documented fact that the 
host plant is enormously benefited due to AM association. Certainly, agriculturists should appreciate the distribution of mycorrhizae within their systems and understood the impact of their management decisions on mycorrhizal functioning. With the fungi, much less fertilizer is needed, reducing the sort of over-fertilization that leads to runoff and contamination of ground water. In Bangladesh, last few years much research has been carried out on different crops to find out the effect vesicular-arbuscular mycorrhiza fungi. Large numbers of VA-mycorrhizal fungi have been detected in different soil types for identification and inoculums production, and for use in nurseries and the field as an alternative to chemical fertilizers and pesticides, and to progress towards nature farming.

Phosphorus is one of the major limiting plant nutrients in soils world over. The presence of phosphorus in the soil encourages plant growth because phosphorus is essential mineral macronutrients. Most of the essential plant nutrients, including phosphorus, remain in insoluble form in soil (Abd-Alla 1994, Yadav \& Verma 2007). Most agricultural soils contain large reserves of phosphorus, a considerable part of which has accumulated as a consequence of regular applications of P fertilizer (Richardson \& Simpson 2011). A large portion of soluble inorganic phosphate when applied on soil as chemical fertilizer is rapidly immobilized soon after application and becomes unavailable to plants (Harrison et al. 1972, Yadav \& Verma 2007). The fixation of native and applied phosphorus either by adsorption or by chemical precipitation is generally considered the main cause of its low availability to crops in vast majority of soils. Therefore, the release of insoluble and fixed forms of phosphorus is an important aspect of increasing soil $\mathrm{P}$ availability.

Soil fertility deterioration is a major constraint for higher crop production in Bangladesh. Due to increasing land use intensity, inadequate and unbalanced use of chemical fertilizers, little or no use of organic manure the fertility of our soils were deteriorating which caused declining of crop production. Soil organic matter is a key factor for sustainable soil fertility and crop productivity. Losses of soil organic matter can only be replenished in the short term by application of organic matter such as manure (Glaser et al. 2001). Cowdung is one of the most important organic materials and good source of organic matter. Cowdung releases nutrient slowly so that nutrient loss is less followed by more plant uptake. It is quite promising to use of organic manure and chemical fertilizers in integrated manner for soil fertility. The present day concern about global environmental pollution can be reduced to a considered extent by the judicious use of chemical fertilizers and increasing the use of organic manure.

Red amaranth (Amaranthus tricolor L.) and Indian spinach (Basella abla L.) both are the important leafy vegetables in Bangladesh member of the family Amaranthaceae Basellaceae, respectively. Red amaranth has been growing in Bangladesh both in winter and summer seasons. It can be harvested within a very short time. Indian spinach is a perennial plant. In cooler areas, it can be grown as an annual during the warmer pant of the year. It is a soft-stemmed vine. The green leaves are thick and semi-succulent. Indian spinach is a very fast growing vine and grows in full sunlight but slowly in high $\mathrm{pH}$ soils. Both the crops are very tasty and nutritious.

The demand for organic vegetables is increasing notably among the health conscious people in our country like elsewhere of the globe. Different leafy vegetables are widely grown throughout the country usually with high doses of chemical fertilizers along with or without organic manure. Because of the beneficial effects of AM fungi on crop plants, it was assumed that combined application of AM fungi with chemical fertilizers and organics manure might improve growth and yield of leafy vegetables. The rate of application of chemical fertilizers might also be reducing with the use of AM bio-fertilizer. This would help reduce the adverse effect of high dose of chemical fertilizer on soils and the cost of production would also be reduced. Keeping the above viewpoint, these experiments were undertaken to evaluate the response of arbuscular mycorrhiza, cowdung and phosphorus on the growth and yield of red amaranth and Indian spinach.

\section{MATERIALS AND METHODS}

Experimental site and location

The experiment was conducted in the net house of the Department of Agricultural Chemistry, Bangladesh Agricultural University, Mymensingh. The climate of the experimental area was under the sub-tropical climatic zone.

\section{Collection and preparation of soil sample}

The soil used in this experiment was collected from Central Farm of Bangladesh Agricultural University, Mymensingh. The soil was dried and the clods were broken and sieved to remove weeds, stubbles and hard clods. Before starting the experiment, the soil was analyzed primarily for its physical and chemical properties. www.tropicalplantresearch.com 
Organic carbon, soil $\mathrm{pH}$, soil texture, cation exchange capacity, total nitrogen, available phosphorus, exchangeable potassium, available sulphur were analyzed.

Table 1. Different properties of experimental soil.

\begin{tabular}{llllllll}
\hline pH & CEC & Total N & Organic carbon Organic matter & Available P & Exchangeable K & Available S \\
\hline 6.18 & $8.4 \%$ & $0.10 \%$ & $0.71 \%$ & $1.16 \%$ & $12.6 \mu \mathrm{g} \cdot \mathrm{g}^{-1}$ & $0.14 \mathrm{cmol} . \mathrm{kg}^{-1}$ & $10.9 \mu \mathrm{g} \cdot \mathrm{g}^{-1}$ \\
\hline
\end{tabular}

Analysis of cowdung

Cowdung manure was analyzed for assessing the constituents of $\mathrm{N}, \mathrm{P}, \mathrm{K}, \mathrm{S}, \mathrm{Ca}, \mathrm{Mg}$ and Fe following the standard methods used for analysis. Total $\mathrm{N}(\%)=1.28, \mathrm{P}(\%)=0.60, \mathrm{~K}(\%)=1.65, \mathrm{Ca}(\%)=0.43, \mathrm{Mg}(\%)=0.28, \mathrm{~S}$ $(\%)=0.16, \mathrm{Fe}(\%)=14.47$.

\section{Test crops}

Red amaranth cv. BARI Lalshak-1 and Indian spinach cv. BARI Puishak-1 were used as plant materials for the experiment. The seeds were collected from Horticulture Research Centre, Bangladesh Agricultural Research Institute, Joydebpur, Gazipur.

\section{Treatment combination and experimental design}

There were eight treatment combinations for each test crop. The experiment was laid out in Completely Randomized Design (CRD) with five replications and total treatment combinations were 40. $\mathrm{T}_{1}=$ Control, $\mathrm{T}_{2}=$ $\mathrm{AM}, \mathrm{T}_{3}=\mathrm{CD}, \mathrm{T}_{4}=\mathrm{P}, \mathrm{T}_{5}=\mathrm{AM}+\mathrm{CD}, \mathrm{T}_{6}=\mathrm{CD}+\mathrm{P}, \mathrm{T}_{7}=\mathrm{AM}+\mathrm{P}, \mathrm{T}_{8}=\mathrm{AM}+\mathrm{CD}+\mathrm{P}$.

Fertilizer dose-

For red amaranth: $\mathrm{AM}=80 \mathrm{~g} /$ polybag, $\mathrm{CD}=20 \mathrm{~g} /$ polybag, $\mathrm{P}=0.30 \mathrm{~g}$ TSP/polybag

Basal dose- Urea @ $110 \mathrm{~kg} \mathrm{ha}^{-1}(0.95 \mathrm{~g} / \mathrm{polybag})$, MOP @ $25 \mathrm{~kg} \mathrm{ha}^{-1}(0.20 \mathrm{~g} / \mathrm{polybag})$ and Gypsum @ $4 \mathrm{~kg} \mathrm{ha}^{-1}$ (89 mg/polybag)

For Indian spinach: $\mathrm{AM}=80 \mathrm{~g} / \mathrm{polybag}, \mathrm{CD}=32 \mathrm{~g} / \mathrm{polybag}, \mathrm{P}=0.30 \mathrm{~g}$ TSP/polybag

Basal dose- Urea @ $120 \mathrm{~kg} \mathrm{ha}^{-1}$ (1.04 g/polybag), MOP @ $50 \mathrm{~kg} \mathrm{ha}^{-1}$ (0.40 g/polybag) and Gypsum @ $13 \mathrm{~kg} \mathrm{ha}$ ${ }^{1}(290 \mathrm{mg} /$ polybag)

Per polybag $8 \mathrm{~kg}$ soil was used. Basal doses were added from Fertilizer Recommendation Guide-2005.

Application of arbuscular mycorrhizal (AM) fungi in soil and sowing of seed

Soil based AM inoculum was used in the seed furrows of about $3 \mathrm{~cm}$ depth at the rate of $80 \mathrm{~g} / \mathrm{polybag}$. Then seeds of each test crop were sown in each furrow on AM inoculums and covered them by side soil. After sowing the seed, the soil was saturated with water.

\section{Collection of data}

Plant height, Plant diameter, Total number of leaves per plant, Shoot and root fresh weights, Root length, Shoot and root dry weights of red amaranth were recorded after 36 DAS and of Indian spinach after 50 DAS, 80 DAS and 110 DAS.

\section{Statistical analyses}

Analysis of variance was done following the Completely Randomized Design (CRD) with the help of computer package MSTAT developed by Russel (1984). The data were analyzed statistically by F-test (Gomez \& Gomez 1984). The mean differences of the treatments were adjusted by the least significant difference (LSD) test.

\section{RESULTS}

Effect of arbuscular mycorrhiza, cowdung and phosphorus on growth and yield contributing characters of red amaranth

Plant height and diameter

Application of AM, CD and $\mathrm{P}$ significantly $(\mathrm{P} \leq 0.01)$ influenced the plant height and diameter of red amaranth (Table 2). Combined application of AM, CD and $\mathrm{P}$ increased plant height and diameter. The highest plant height and diameter was recorded from $T_{8}$ treatment $(A M+C D+P)$ which was statistically identical with $\mathrm{T}_{6}$ treatment $(\mathrm{CD}+\mathrm{P})$ in the case of plant height and $\mathrm{T}_{7}$ treatment $(\mathrm{AM}+\mathrm{P})$ in the case of diameter. The lowest plant height and diameter was obtained in $\mathrm{T}_{1}$ (control) treatment. Results suggested that AM biofertilizer along with phosphorus and $\mathrm{CD}$ application exert a positive effect on plant height and diameter of red amaranth. Application of only AM, CD and P showed significantly higher plant height and diameter over control plant. 
Number of leaves per plant

Significant $(\mathrm{P} \leq 0.01)$ effect of $\mathrm{AM}, \mathrm{CD}$ and $\mathrm{P}$ was found on number of leaves per plant in red amaranth (Table 2). The highest number of leaves per plant was observed in $\mathrm{T}_{8}$ where $\mathrm{AM}, \mathrm{CD}$ and phosphorus were applied. The treatment $\mathrm{T}_{6}(\mathrm{CD}+\mathrm{P}), \mathrm{T}_{5}(\mathrm{AM}+\mathrm{CD}), \mathrm{T}_{4}(\mathrm{P}), \mathrm{T}_{3}(\mathrm{CD})$ and $\mathrm{T}_{2}(\mathrm{AM})$ all were statistically identical. It was noted that the number of leaves per plant increased successively with the application of AM.

Fresh and dry weight per plant

Significant $(\mathrm{P} \leq 0.01)$ variation in fresh and dry weight of red amaranth was observed due to the effect of $\mathrm{AM}, \mathrm{CD}$ and $\mathrm{P}$ (Table 2). It was observed that the maximum plant fresh and dry weight was recorded in $\mathrm{T}_{8}(\mathrm{AM}$ $+\mathrm{CD}+\mathrm{P})$ that was significantly higher than all other treatments. The lowest fresh and dry weight was obtained in treatment $\mathrm{T}_{1}$ (control). Combined effect of $\mathrm{AM}$ and $\mathrm{P}$ in $\mathrm{T}_{7}$ was showed statistically identical fresh and dry weight per plant with $\mathrm{T}_{2}(\mathrm{AM}), \mathrm{T}_{3}(\mathrm{CD}), \mathrm{T}_{4}(\mathrm{P}) \mathrm{T}_{5}(\mathrm{AM}+\mathrm{CD})$ and $\mathrm{T}_{6}(\mathrm{CD}+\mathrm{P})$.

Root length

The result revealed that root length and fresh weight of red amaranth varied significantly $(\mathrm{P} \leq 0.05)$ by the effect of AM, CD and $\mathrm{P}$ (Table 2). The highest root length and fresh weight was recorded from $\mathrm{T}_{8}$ treatment $(A M+C D+P)$ and the lowest length was recorded in $\mathrm{T}_{1}$ (control). Root length of $\mathrm{T}_{5}, \mathrm{~T}_{6}$ and $\mathrm{T}_{7}$ treatments were higher than $\mathrm{T}_{2}, \mathrm{~T}_{3}$ and $\mathrm{T}_{4}$, respectively. This indicated that application of $\mathrm{AM}+\mathrm{CD}, \mathrm{CD}+\mathrm{P}$ or $\mathrm{AM}+\mathrm{P}$ always gave higher root length than individual application of AM, CD or P.

Table 2. Effect of arbuscular mycorrhiza (AM), cowdung (CD) and phosphorus (P) on growth and yield of red amaranth (after 36 days of sowing).

\begin{tabular}{lccccccc}
\hline Treatments & $\begin{array}{c}\text { Plant } \\
\text { height } \\
(\mathbf{c m})\end{array}$ & $\begin{array}{c}\text { Plant } \\
\text { diameter } \\
(\mathbf{c m})\end{array}$ & $\begin{array}{c}\text { Number of } \\
\text { leaf per } \\
\text { plant }\end{array}$ & $\begin{array}{c}\text { Shoot fresh } \\
\text { weight per plant } \\
(\mathbf{g})\end{array}$ & $\begin{array}{c}\text { Shoot dry } \\
\text { weight per plant } \\
(\mathbf{g})\end{array}$ & $\begin{array}{c}\text { Root } \\
\text { length } \\
(\mathbf{c m})\end{array}$ & $\begin{array}{c}\text { Root fresh } \\
\text { weight per plant } \\
(\mathbf{g})\end{array}$ \\
\hline $\mathrm{T}_{1}:$ Control & $18.5 \mathrm{e}$ & $0.20 \mathrm{~d}$ & $8.07 \mathrm{~d}$ & $1.29 \mathrm{c}$ & $0.17 \mathrm{c}$ & $3.58 \mathrm{~b}$ & $0.19 \mathrm{c}$ \\
$\mathrm{T}_{2}: \mathrm{AM}$ & $27.2 \mathrm{~d}$ & $0.46 \mathrm{c}$ & $11.2 \mathrm{c}$ & $10.8 \mathrm{~b}$ & $0.79 \mathrm{~b}$ & $4.55 \mathrm{ab}$ & $0.68 \mathrm{~b}$ \\
$\mathrm{~T}_{3}: \mathrm{CD}$ & $34.3 \mathrm{bcd}$ & $0.52 \mathrm{c}$ & $12.7 \mathrm{bc}$ & $12.0 \mathrm{~b}$ & $0.95 \mathrm{~b}$ & $5.04 \mathrm{ab}$ & $0.96 \mathrm{ab}$ \\
$\mathrm{T}_{4}: \mathrm{P}$ & $36.3 \mathrm{bc}$ & $0.53 \mathrm{c}$ & $12.4 \mathrm{bc}$ & $11.2 \mathrm{~b}$ & $0.79 \mathrm{~b}$ & $5.66 \mathrm{a}$ & $0.97 \mathrm{ab}$ \\
$\mathrm{T}_{5}: \mathrm{AM}+\mathrm{CD}$ & $35.6 \mathrm{bd}$ & $0.56 \mathrm{bc}$ & $13.4 \mathrm{abc}$ & $11.5 \mathrm{~b}$ & $1.07 \mathrm{~b}$ & $4.81 \mathrm{ab}$ & $0.93 \mathrm{ab}$ \\
$\mathrm{T}_{6}: \mathrm{CD}+\mathrm{P}$ & $38.2 \mathrm{ab}$ & $0.57 \mathrm{abc}$ & $12.8 \mathrm{bc}$ & $13.4 \mathrm{~b}$ & $1.05 \mathrm{~b}$ & $5.22 \mathrm{a}$ & $0.98 \mathrm{ab}$ \\
$\mathrm{T}_{7}: \mathrm{AM}+\mathrm{P}$ & $39.3 \mathrm{ab}$ & $0.69 \mathrm{ab}$ & $15.2 \mathrm{ab}$ & $14.2 \mathrm{ab}$ & $1.13 \mathrm{~b}$ & $5.44 \mathrm{a}$ & $1.20 \mathrm{a}$ \\
$\mathrm{T}_{8}: \mathrm{AM}+\mathrm{CD}+\mathrm{P}$ & $45.7 \mathrm{a}$ & $0.70 \mathrm{a}$ & $16.4 \mathrm{a}$ & $17.9 \mathrm{a}$ & $1.80 \mathrm{a}$ & $6.03 \mathrm{a}$ & $1.29 \mathrm{a}$ \\
$\mathrm{LSD}(0.05)$ & 8.67 & 0.13 & 3.12 & 3.87 & 0.39 & 1.56 & 0.45 \\
$\mathrm{CV}(\%)$ & 3.64 & 11.26 & 5.60 & 7.90 & 9.26 & 9.02 & 9.66 \\
Level of sig. & $* *$ & $* *$ & $* *$ & $* *$ & $* *$ & $*$ & $* *$
\end{tabular}

Note: $*$ Significant at $5 \% ; * *$ significant at $1 \%$ level of probability; In a column, the figure(s) having same letter are not significantly different at $5 \%$ level of probability by DMRT.

Table 3. Correlation matrix among growth and yield attributes of red amaranth.

\begin{tabular}{lcccccc}
\hline Characters & \multicolumn{5}{c}{ Correlation coefficient (r value) } \\
\cline { 2 - 7 } & $\begin{array}{c}\text { Plant } \\
\text { height } \\
(\mathbf{c m})\end{array}$ & $\begin{array}{c}\text { Plant } \\
\text { diameter } \\
(\mathbf{c m})\end{array}$ & $\begin{array}{c}\text { Number of } \\
\text { leaf per plant }\end{array}$ & $\begin{array}{c}\text { Shoot fresh } \\
\text { weight per plant } \\
(\mathbf{g m})\end{array}$ & $\begin{array}{c}\text { Shoot dry } \\
\text { weight per plant } \\
(\mathbf{g m})\end{array}$ & $\begin{array}{c}\text { Root } \\
\text { length } \\
(\mathbf{c m})\end{array}$ \\
\hline Plant diameter & $0.702^{* *}$ & & & & \\
No. of leaf per plant & $0.490^{* *}$ & $0.745^{* *}$ & & & \\
Shoot fresh weight & $0.689^{* *}$ & $0.789^{* *}$ & $0.735^{* *}$ & & \\
Shoot dry weight & $0.743^{* *}$ & $0.759^{* *}$ & $0.623^{* *}$ & $0.742^{* *}$ & $0.461^{* *}$ & \\
Root length & $0.356^{*}$ & $0.396^{*}$ & $0.446^{* *}$ & $0.629^{* *}$ & $0.686^{* *}$ & $0.437^{* *}$ \\
Root fresh weight & $0.762^{* *}$ & $0.738^{* *}$ & $0.644^{* *}$ & $0.761^{* *}$ & & \\
\hline
\end{tabular}

Note: $* *=$ Significant at $1 \%$ level of probability.

The treatment $\mathrm{T}_{7}(\mathrm{AM}+\mathrm{P})$ achieved comparatively higher root fresh weight than $\mathrm{T}_{4}$ with phosphorus. No significant differences in root fresh weights were observed in $\mathrm{T}_{3}(\mathrm{CD}), \mathrm{T}_{4}(\mathrm{P}), \mathrm{T}_{5}(\mathrm{AM}+\mathrm{CD})$ and $\mathrm{T}_{6}(\mathrm{CD}+\mathrm{P})$ treatments. It is revealed from the results that AM application with phosphorus and $\mathrm{CD}$ exerted some effect on increasing the fresh weight of root per plant. 


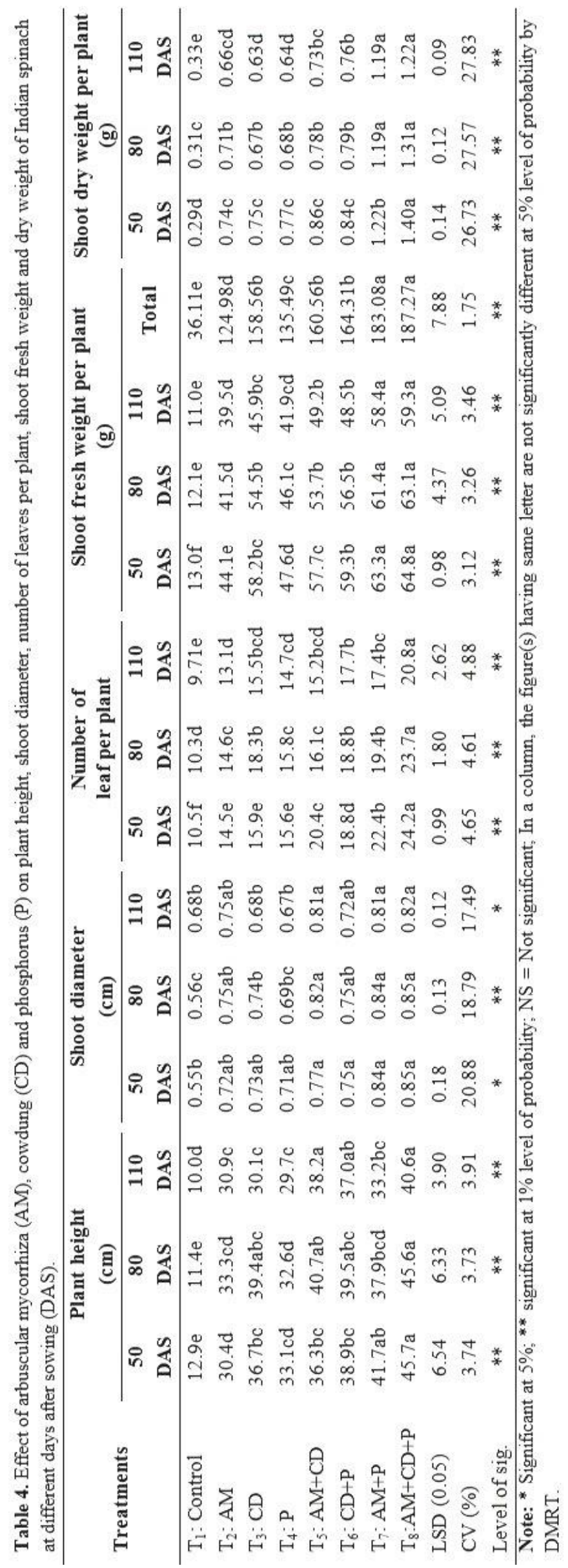

www.tropicalplantresearch.com 
Correlation among growth and yield attributes of red amaranth

The correlation between different growth parameters of red amaranth are shown in table 3 . In the present experiment, shoot fresh weight (yield) was significantly positive correlated with plant height, shoot diameter, leaves number and root length $(\mathrm{P} \leq 0.01)$. Also, most of the plant characters were strongly correlated among themselves.

\section{Effect of AM, cowdung and phosphorus on growth and yield contributing characters of Indian spinach Plant height and diameter}

The plant height and diameter of Indian spinach was positively influenced by the application of AM and CD with P (Table 4). Significant variation was observed in Indian spinach at 50, 80 and 110 days after sowing (DAS). The highest plant heights were recorded in $\mathrm{T}_{8}$ treatment $(\mathrm{AM}+\mathrm{CD}+\mathrm{P})$ which were higher than all other treatments. At $50 \mathrm{DAS}$, the second highest plant height was noted in $\mathrm{T}_{7}$ treatment $(\mathrm{AM}+\mathrm{P})$ which was identical with $\mathrm{T}_{3}(\mathrm{CD}), \mathrm{T}_{5}(\mathrm{AM}+\mathrm{CD})$ and $\mathrm{T}_{6}(\mathrm{CD}+\mathrm{P})$ treatments. At $80 \mathrm{DAS}$, application of AM and cowdung ( $\mathrm{T}_{5}$ treatment) produced the second highest plant height that was statistically identical with $\mathrm{T}_{3}(\mathrm{CD}), \mathrm{T}_{6}(\mathrm{CD}+\mathrm{P})$ and $\mathrm{T}_{7}(\mathrm{AM}+\mathrm{P})$. But at $110 \mathrm{DAS}$, the same treatment $\left(\mathrm{T}_{5}\right)$ gave the second highest plant height which was identical with $\mathrm{T}_{6}(\mathrm{CD}+\mathrm{P})$ and $\mathrm{T}_{8}(\mathrm{AM}+\mathrm{CD}+\mathrm{P})$. The lowest plant heights were found in control treatment.

At $50 \mathrm{DAS}$, the shoot diameters were found in $\mathrm{T}_{8}(\mathrm{AM}+\mathrm{CD}+\mathrm{P})$ and in $\mathrm{T}_{7}(\mathrm{AM}+\mathrm{P})$ treatments which were comparatively higher than all other treatments but statistically identical with all the treatments except control treatment. At $110 \mathrm{DAS}$, the treatment $\mathrm{T}_{8}(\mathrm{AM}+\mathrm{CD}+\mathrm{P})$ produced highest shoot diameter and $\mathrm{T}_{7}(\mathrm{AM}+\mathrm{P})$ and $\mathrm{T}_{5}(\mathrm{AM}+\mathrm{CD})$ gave same shoot diameter. The treatments $\mathrm{T}_{8}, \mathrm{~T}_{7}, \mathrm{~T}_{6}, \mathrm{~T}_{5}$ and $\mathrm{T}_{2}$ gave statistically similar results. At 80 DAS, the maximum shoot diameter was obtained where plants were treated with AM, CD and phosphorus that was statistically identical with all the treatment except $\mathrm{T}_{4}$ with phosphorus and control treatment. Application of AM with CD achieved shoot diameter which was higher than $\mathrm{T}_{3}$ without AM at 80 DAS but statistically similar. When AM was used in $\mathrm{T}_{2}$, it gave better response to control treatment.

\section{Number of leaves per plant}

The number of leaves per plant was statistically significant $(\mathrm{P} \leq 0.01)$ due to application of $\mathrm{AM}, \mathrm{CD}$ and $\mathrm{P}$ at three stage of harvesting (Table 4). The maximum number of leaves per plant were obtained with application of AM, CD and P combinedly which was superior to all other treatments. At 110 DAS, combined application of $\mathrm{CD}$ and phosphorus in $\mathrm{T}_{6}$ treatment achieved the second highest number of leaves per plant which was identical with $\mathrm{T}_{7}(\mathrm{AM}+\mathrm{P})$ but different from all other treatments. In three stages of harvesting, control gave the lowest number of leaves per plant than the treatments treated with AM biofertilizer. Application of arbuscular mycorrhiza with CD in 50 and 80 DAS obtained higher response than the treatment treated without arbuscular mycorrhiza but found statistically identical result at 110 DAS.

At $50 \mathrm{DAS}, \mathrm{T}_{6}(\mathrm{CD}+\mathrm{P})$ produced number of leaves per plant which was higher than $\mathrm{T}_{3}(\mathrm{CD})$. At $80 \mathrm{DAS}$, application of $\mathrm{CD}$ with phosphorus achieved numbers of leaves per plant which was higher than the results found in $\mathrm{T}_{4}$ with phosphorus but statistically identical with $\mathrm{T}_{3}$ where $\mathrm{CD}$ was used without phosphorus. Application of CD with arbuscular mycorrhiza in $\mathrm{T}_{5}$ produced higher value than the treatment treated with $\mathrm{AM}$ but statistically similar with $\mathrm{T}_{3}(\mathrm{CD})$ at $110 \mathrm{DAS}$.

\section{Shoot fresh weight}

Shoot fresh weight of Indian spinach was influenced significantly $(\mathrm{P} \leq 0.05)$ by the application of $A M$, phosphorus and CD (Table 4). The maximum shoot fresh weight was recorded in $\mathrm{T}_{8}(\mathrm{AM}+\mathrm{CD}+\mathrm{P})$ plants at 50 DAS, 80 DAS and 110 DAS which was identical to $\mathrm{T}_{7}(\mathrm{AM}+\mathrm{P})$. At each stage of harvesting, the shoot fresh weights of Indian spinach gave better response with the application of $\mathrm{AM}$ and $\mathrm{P}$ in $\mathrm{T}_{7}$ than the plants was treated without $\mathrm{AM}$ in $\mathrm{T}_{4}$, respectively. Application of $\mathrm{AM}$ in $\mathrm{T}_{2}$ produced shoot fresh weights which were much higher than control treatment. Application of CD was significantly influenced the shoot fresh weight of Indian spinach.

\section{Shoot dry weight}

Shoot dry weight of Indian spinach was significantly $(\mathrm{P} \leq 0.01)$ influenced by arbuscular mycorrhiza, $\mathrm{CD}$ and phosphatic fertilizer (Table 4). Maximum dry weight was recorded in $\mathrm{T}_{8}$ treatment $(\mathrm{AM}+\mathrm{CD}+\mathrm{P})$ at 50,80 and 110 DAS. At 50, 80 and 110 DAS, the shoot dry weights were found in $\mathrm{T}_{7}(\mathrm{AM}+\mathrm{P})$ which were statistically higher than $\mathrm{T}_{4}(\mathrm{P})$. Application of arbuscular mycorrhiza with $\mathrm{CD}$ produced the shoot dry weights in $\mathrm{T}_{5}$ which were higher than the value found in $\mathrm{T}_{3}(\mathrm{CD})$ at 50, 80 and $110 \mathrm{DAS}$, respectively. Application of $\mathrm{AM}$ in $\mathrm{T}_{2}$ 
produced dry weight which was statistically higher than control treatment at 50 DAS. Same indication was observed at 80 and 110 DAS.

Root length at 110 DAS

The result revealed that root length of Indian spinach did not vary significantly $(\mathrm{P} \leq 0.01)$ by the effect of $\mathrm{AM}, \mathrm{CD}$ and $\mathrm{P}$ (Table 5). With respect to root length, the highest length was recorded from $\mathrm{T}_{8}$ treatment $(\mathrm{AM}+$ $\mathrm{CD}+\mathrm{P}$ ) and the lowest length was recorded in $\mathrm{T}_{1}$ (control). Statistically there were no differences among root lengths of $\mathrm{T}_{5}(\mathrm{AM}+\mathrm{CD}), \mathrm{T}_{6}(\mathrm{CD}+\mathrm{P})$ and $\mathrm{T}_{7}(\mathrm{AM}+\mathrm{P})$ treatments.

Table 5. Effect of arbuscular mycorrhiza (AM), cowdung (CD) and phosphorus (P) on root length, fresh and dry weights of Indian spinach at 110 DAS.

\begin{tabular}{lccc}
\hline \multicolumn{1}{c}{ Treatments } & $\begin{array}{c}\text { Root length } \\
(\mathbf{c m})\end{array}$ & $\begin{array}{c}\text { Root fresh weight } \\
(\mathbf{g m})\end{array}$ & $\begin{array}{c}\text { Root dry weight } \\
\text { (gm) }\end{array}$ \\
\hline $\mathrm{T}_{1}:$ Control & 10.8 & $3.87 \mathrm{e}$ & $1.32 \mathrm{~d}$ \\
$\mathrm{~T}_{2}: \mathrm{AM}$ & 13.0 & $14.4 \mathrm{c}$ & $5.57 \mathrm{~b}$ \\
$\mathrm{~T}_{3}: \mathrm{CD}$ & 13.1 & $10.7 \mathrm{~d}$ & $4.46 \mathrm{c}$ \\
$\mathrm{T}_{4}: \mathrm{P}$ & 11.9 & $14.5 \mathrm{c}$ & $5.74 \mathrm{~b}$ \\
$\mathrm{~T}_{5}: \mathrm{AM}+\mathrm{CD}$ & 13.5 & $16.8 \mathrm{~b}$ & $6.91 \mathrm{a}$ \\
$\mathrm{T}_{6}: \mathrm{CD}+\mathrm{P}$ & 13.5 & $15.1 \mathrm{c}$ & $6.07 \mathrm{~b}$ \\
$\mathrm{~T}_{7}: \mathrm{AM}+\mathrm{P}$ & 13.4 & $19.0 \mathrm{a}$ & $7.59 \mathrm{a}$ \\
$\mathrm{T}_{8}: \mathrm{AM}+\mathrm{CD}+\mathrm{P}$ & 14.3 & $19.3 \mathrm{a}$ & $7.68 \mathrm{a}$ \\
$\mathrm{LSD}(0.05)$ & 3.58 & 1.34 & 0.79 \\
$\mathrm{CV}(\%)$ & 5.07 & 6.15 & 10.01 \\
Level of sig. & $\mathrm{NS}$ & $* *$ & $* *$ \\
\hline
\end{tabular}

Note: $* *$ Significant at $1 \%$ level of probability; NS = Not significant; In a column, the figure(s) having same letter are not significantly different at $5 \%$ level of probability by DMRT.

\section{Root fresh and dry weight at 110 DAS}

The result showed that root fresh and dry weight of Indian spinach varied significantly $(\mathrm{P} \leq 0.01)$ by the application of AM, CD and $\mathrm{P}$ (Table 5). The highest root fresh and dry weight was recorded in $\mathrm{T}_{8}$ treatment where $A M, C D$ and $P$ were applied which was statistically identical with the result found in $T_{7}(A M+P)$ and $T_{5}$ in case of dry weight only. Control treatment produced the lowest root fresh and dry weight. Application of AM in $\mathrm{T}_{2}$ achieved comparatively higher root fresh and dry weight per plant than control. Use of AM with $C D$ in $T_{5}$ achieved higher fresh weight value than the plants was treated without arbuscular mycorrhiza in $\mathrm{T}_{3}$. Application of $\mathrm{CD}$ with phosphorus in $\mathrm{T}_{6}$ produced root fresh and dry weight which was statistically similar with the root fresh weight found in $\mathrm{T}_{4}$ without $\mathrm{CD}$.

Correlation among growth and yield attributes of Indian spinach

The correlation between different growth parameters at 110 DAS are shown in Table-6. In the experiment shoot fresh weight (yield) was significantly positive correlated with plant height, shoot diameter, leaves number, root length and root fresh weight. Also among the growth parameters there were found positive correlations.

Table 6. Correlation matrix among growth and yield attributes of Indian spinach at 110 DAS.

\begin{tabular}{|c|c|c|c|c|c|c|c|}
\hline \multirow[b]{2}{*}{ Characters } & \multicolumn{7}{|c|}{ Correlation coefficient ( $r$ value) } \\
\hline & $\begin{array}{c}\text { Plant } \\
\text { height }\end{array}$ & $\begin{array}{c}\text { Shoot } \\
\text { Diameter }\end{array}$ & $\begin{array}{c}\text { Number of } \\
\text { leaf per plant }\end{array}$ & $\begin{array}{c}\text { Shoot fresh } \\
\text { weight }\end{array}$ & $\begin{array}{c}\text { Shoot } \\
\text { dry weight }\end{array}$ & $\begin{array}{c}\text { Root } \\
\text { length }\end{array}$ & $\begin{array}{c}\text { Root fresh } \\
\text { Weight }\end{array}$ \\
\hline Shoot diameter & $0.408 * *$ & & & & & & \\
\hline Number of leaf par plant & $0.748 * *$ & $0.316^{*}$ & & & & & \\
\hline Shoot fresh weight & $0.860 * *$ & $0.379 *$ & $0.757 * *$ & & & & \\
\hline Shoot dry weight & $0.688 * *$ & $0.401 * *$ & $0.739 * *$ & $0.837 * *$ & & & \\
\hline Root length & $0.342 *$ & $0.102^{\mathrm{NS}}$ & $0.410 * *$ & $0.345^{*}$ & $0.275^{\mathrm{NS}}$ & & \\
\hline Root fresh weight & $0.842 * *$ & $0.479 * *$ & $0.696 * *$ & $0.906 * *$ & $0.826 * *$ & $0.327 *$ & \\
\hline Root dry weight & $0.849 * *$ & $0.382 *$ & $0.734 * *$ & $0.894 * *$ & $0.817 * *$ & $0.366^{*}$ & $0.928 * *$ \\
\hline
\end{tabular}

Note: * = Significant at $5 \%$ level of probability; ** = Significant at $1 \%$ level of probability; NS= Non Significant. 


\section{DISCUSSION}

Different growth parameters such as plant height, plant diameter and number of leaves per plant are positively correlated with the yield of red amaranth and Indian spinach. The present study revealed that AM inoculants had significant effect on plant growth of red amaranth and Indian spinach. Similar finding was reported by (Karagiannidis et al. 2002) in tomato and egg plants, (Ergin \& Gülser 2016) in lettuce and (Caglar \& Akgun 2006) in three Pistacia species, who found that mycorrhiza treatment increased plant growth compared to control. Results indicated that application of cowdung with phosphorus fertilizer increased the plant height, diameter and number of leaves. This result was supported by Wang et al. (2006) and Jin et al. (1996) where they reported that application of cattle manure resulted in an increase of plant height. Bargali (2006) observed the effect of AM inoculation on growth performance of Indigofera heterantha at seedling stage. He found that arbuscular mycorrhiza fungi inoculation resulted in $5.9 \mathrm{~cm}$ increment in shoot length and with increasing time the positive effect of AM fungi inoculation was also increased. From the results stated above suggested that AM biofertilizer along with phosphorus and cowdung application exert positive effect on plant height of red amaranth and Indian spinach.

Mycorrhizal inoculation improved higher shoot diameter in AM inoculated seedlings than in non-inoculated seedlings (Giri et al. 2005). The shoot diameter of Indian spinach was always higher in the treatments where cowdung was applied with phosphorus or AM than individual application of CD or P or AM. Similar result was reported by Subhan (1988) that application of organic manure increased the head diameter of cabbage. The result showed that the plant diameter of red amaranth and Indian spinach was significantly influenced by the effect of AM biofertilizer, cowdung and phosphorus (Guo et al. 2006).

It is revealed from the results that AM along with phosphorus and cowdung application exerted significant effect on increasing the number of leaves per plant. Similar result was found by (Lins et al. 2006) in Leucaena leucocephala (Lam.) and (Samanhudi et al. 2014) in ginger.

Shoot fresh weight and dry weight of red amaranth and Indian spinach was also influenced significantly by the application of AM, phosphorus and CD. Shoot fresh and dry weight was increased by AM colonization (Tawaraya et al. 2006). The shoot dry weight was increased with AM inoculation (Andersen \& Andersen 2006) and the increasing rate of manure (Asghari et al. 2015). Under nursery conditions mycorrhizal inoculation improved growth of Glomus fasciculatum, G. macrocarpum and Cassia siamea seedlings. Shoot dry weight was higher in mycorrhizal than non-mycorrhizal plants (Giri et al. 2005).

Arbuscular mycorrhiza fungi inoculation resulted in $1.9 \mathrm{~cm}$ increment in root length and with increasing time the positive effect of AM fungi inoculation also increased in Indigofera heterantha at seedling stage (Bargali 2006) Similar result was found in the present study that AM application increased root length of red amaranth and Indian spinach significantly. It is also revealed from the results that AM application with phosphorus and cowdung exerted some effect on increasing the fresh weight of root per plant. Similarly, (Akkopru \& Demir 2005) observed that arbuscular mycorrhizal fungus (AMF) Glomus intraradices increased morphological parameters (fresh root weight). The application of organic manure increased the yield of the vegetables compared to vegetables applied with chemical fertilizers (Yan \& An-cheng 2004).

In present study, most of the plant characters were strongly correlated among themselves. Similarly, Sarkar et al. (2002) reported that correlation coefficient studies showed high correlation between yield and root weight, shoot length and shoot fresh weight. Also (Solaiman 1999) found positive correlation among mungbean growth, N uptake and yield parameters. Similar correlations were observed by Begum (2004).

\section{CONCLUSION}

From the above findings, it may be concluded that application of arbuscular mycorrhiza biofertilizer along with cowdung and phosphorus observed better performance on growth, yield. The study ventilated that AM use as a biofertilizer and cowdung as organic manure for production of red amaranth and Indian spinach reduced phosphatic fertilizer uses which ultimately reduced our cost.

\section{REFERENCES}

Abd-Alla MH (1994) Phosphatases and the utilization of organic phosphorus by Rhizobium leguminosarum biovar viceae. Letters in Applied Microbiology 18: 294-296.

Akkopru A \& Demir S (2005) Biological control of Fusarium wilt in tomato caused by Fusarium oxysporum $\mathrm{f}$.

sp. lycopersici by AMF Glomus intraradices and some rhizobacteria. Journal of Phytopathology 550: 544- 
550.

Andersen FO \& Andersen T (2006) Effects of arbuscular mycorrhizae on biomass and nutrients in the aquatic plant (Littorella uniflora). Freshwater Biology 51: 1623-1633.

Asghari MT, Mir R \& Fard A (2015) The effect of farm yard manure and nitrogen fertilizer on some characteristics of potato (Solanum tuberosum var. Agria). Biharean Biologist 9: 81-84.

Balestrini R \& Lanfranco L (2006) Fungal and plant gene expression in arbuscular mycorrhizal symbiosis. Mycorrhiza 16: 509-524.

Bargali K (2006) Response of Indigofera heterantha seedlings to inoculation with vesicular-arbuscular mycorrhizal fungi. Proceedings of the Indian National Science Academy. Part B Biological Sciences 4: 373376.

Begum RA (2006) Assessment of water and soil pollution and its impact on rice and red amaranth. Conservation \& Recycling 48(1): 86-98.

Caglar S \& Akgun A (2006) Effects of vesicular - Arbuscular mycorrhizal (VAM) fungi on the seedling growth of three Pistacia species. Journal of Environmental Biology 27: 485-489.

Danneberg G, Latus C, Zimmer W, Hundeshagen B, Schneider-Poetsch Hj \& Bothe H (1993) Influence of vesicular-arbuscular mycorrhiza on phytohormone balances in maize (Zea mays L.). Journal of Plant Physiology 141: 33-39.

Ergin SF \& Gülser F (2016) Effect of mycorrhiza on growth criteria and phosphorus nutrition of lettuce (Lactuca sativa L .) under different phosphorus application rates. Eurasian Journal of Soil Science 5: 275278.

Giri B, Kapoor R \& Mukerji KG (2005) Effect of the arbuscular mycorrhizae Glomus fasciculatum and G. macrocarpum on the growth and nutrient content of Cassia siamea in a semi-arid Indian wasteland soil. New Forester 29: 63-73.

Glaser B, Lehmann J, Führböter M, et al (2001) Carbon and nitrogen mineralization in cultivated and natural savanna soils of Northern Tanzania. Biology and Fertility of Soils 33: 301-309.

Gomez A \& Gomez K (1984) Statistical procedures for agricultural research, $2^{\text {nd }}$ edition. John Wiley \& Sons, Inc., USA, pp. 680.

Guo T, Zhang JL, Christie P \& Li XL (2006) Effects of arbuscular mycorrhizal fungi and ammonium: Nitrate ratios on growth and pungency of onion seedlings. Journal of Plant Nutrition 29: 1047-1059.

Harrison MJ, Pacha RE \& Morita RY (1972) Solubilization of inorganic phosphates by bacteria isolated from upper Klamath Lake sediment. Limnology and Oceanography 17: 50-57.

Jin HJ, Kim JG, Cho YM, Kway JH, Shin JS \& Lee HH (1996) Growth, yields and quality of rice cultivated on paddy soils as after crop fodder rye under heavy application of animal manure. Journal of The Korean Society of Grassland and Forage Science 16(4): 338-342

Karagiannidis N, Bletsos F \& Stavropoulos N (2002) Effect of Verticillium wilt (Verticillium dahliae Kleb.) and mycorrhiza (Glomus mosseae) on root colonization, growth and nutrient uptake in tomato and eggplant seedlings. Scientia Horticulturae 94: 145-156.

Lins CEL, Cavalcante UMT, Sampaio EVSB, et al (2006) Growth of mycorrhized seedlings of Leucaena leucocephala (Lam.) de Wit. in a copper contaminated soil. Applied Soil Ecology 31: 181-185.

Marschner H \& Dell B (1994) Nutrient uptake in mycorrhizal symbiosis. Plant Soil 159: 89-102.

Richardson AE \& Simpson RJ (2011) Soil Microorganisms Mediating Phosphorus Availability Update on Microbial Phosphorus. Plant Physiology 156: 989-996.

Russel DF (1984) M-STAT Director. Crop and Soil Science Dept. Michigan State University, USA.

Samanhudi, Yunus A, Pujiasmanto B \& Rahayu M (2014) Effect of Organic Manure and Arbuscular Mycorrhizal Fungi on Growth and Yield of Young Ginger (Zingiber officinale Rosc.). IOSR Journal of Agriculture and veterinary Science 7: 1-5.

Sarkar HK, Pal AK \& Baisya R (2002) Effect of Bradyrhizobium inoculation on blackgram [Vigna mungo (L.) Hepper] with special reference to root and nodule parameters. Journal of Interacademicia 6(3): 260-265.

Solaiman A (1999) Response of mungbean to Bradyrhizobium sp.(Vigna) inoculation with and without phosphorus and potassium fertilization. Bangladesh Journal of Scientific Research 17: 125-132.

Subhan (1988) Effect of organic materials on growth and production of cabbage (Brassica oleracea L.). Bulletin of Penelition Hortikultur 16(4): 37-41 
Tawaraya K, Naito M \& Wagatsuma T (2006) Solubilization of Insoluble Inorganic Phosphate by Hyphal Exudates of Arbuscular Mycorrhizal Fungi. Journal of Plant Nutrition 29: 657-665.

Yadav BK \& Verma A (2007) Phosphate Solubilization and Mobilization in Soil Through Microorganisms Under Arid Ecosystems. In: Ali M (ed) The Functioning of Ecosystems. InTechOpen, pp. 332.

Yan Z \& An-cheng L (2004) Effect of organic manure on the quality of vegetables in plastic-sheet-covered sheds. Acta Agriculturae Zhejiangensis 16: 210-212.

Wang Y, Hung Q, Meng L \& Shen Q (2006) Effect of combined application of organic and inorganic fertilizer application on growth of spinach and soil nitrogen supply. Journal of Nanjing Agricultural University 29(3): 44-48. 